\title{
Role of natural antioxidants in the therapeutic management of hepatocellular carcinoma
}

\author{
Hanaa A. Hassan ${ }^{1}$, Nermin E. El-Gharib' ${ }^{1}$, Anmar F. Azhari ${ }^{2}$ \\ ${ }^{1}$ Physiology Division, Zoology Department, Faculty of Science, Mansoura University, Mansoura 35516, Egypt. \\ ${ }^{2}$ Ministry of Health, Makkah Region, Makkah 21514, Saudi Arabia.
}

\begin{abstract}
Hepatocellular carcinoma (HCC) is a growing health problem in humans. HCC is considered the most common of internal malignancy which cause the death of human, but in the developed Western world, HCC is less common accompanied by increasing essentially in incidence, due to it occurs specially in chronic liver disease. HCC associated with various risk factors including hepatitis B virus infection; hepatitis $\mathrm{C}$ virus infection; prolonged aflatoxin exposure; and alcoholic cirrhosis. Overall, one-third of cirrhosis patients will develop HCC during their life time. Also, chemical carcinogens cause tumor promotions through free radical metabolites result in many biochemical and molecular changes that induces oxidative stress. The identify of HCC stage and underlying liver status then choosing the most appropriate line of therapy (surgical, loco regional, radiological and medical) can be improve the survival and/or the quality of life of the patient. Taken into the account of the nutritional value of some natural antioxidant agents that support the function of the body resulting an improvement of the health and protection from different diseases, our review will provide an up-dated status of the different aspects of HCC management through covering the efficacy and the beneficial effects of different natural agents and their mechanism of action against HCC for the future therapy modalities.
\end{abstract}

Key words: Hepatocellular carcinoma; risk factors; natural antioxidants

Corresponding Author:

Prof. Hanaa A. Hassan, Physiology Division, Zoology Department, Faculty of Science, Mansoura University, Mansoura 35516, Egypt. E-mail: drhanaahassan@mans.edu.eg

Received: 30-04-2016, Accepted: 04-07-2016

\section{INTRODUCTION}

Hepatocellular carcinoma (HCC) incidence is the most common tumor in worldwide. ${ }^{[1]}$ HCC involves major changes in multiple molecular pathways, genetic and epigenetic factors, which consequently leads to the malignant transformation and HCC progression. ${ }^{[2]}$ Chronic liver disease and cirrhosis of patients cause HCC. HCC has major risk factors for developing cirrhosis such as, alcoholic consumbtion, hepatitis B virus (HBV) and hepatitis C virus (HCV) and nonalcoholic steatohepatitis..$^{[2]}$ Additionally, the contamination of water by chemicals, diabetes, obesity and genetic factors including hemochromatosis, and some physiological disorders act as risk factors for developing HCC. ${ }^{[3]}$ Cirrhosis is the most dangerous factors

\begin{tabular}{|l|c|}
\hline \multicolumn{3}{|c|}{ Access this article online } \\
Website: & Quick Response Code \\
http://www.hrjournal.net/ & \\
& \\
DOI: &
\end{tabular}

for HCC, especially cirrhosis which caused by hepatitis virus infections. ${ }^{[4]}$ Therefore, increasing HCC risks occur in the acquired HBV during the childbirth and early childhood..$^{|5|}$ The patients with HCC present with one or more of several clinical features as weight loss, right upper. HCC causes acute disaster of abdominal by bleeding intra-abdominal or extra hepatic appearance. ${ }^{[6]}$ Also, patients have HCC with cirrhosis cause palmarerythema, obstractive jaundice, gynecomastia and portal hypertension. ${ }^{[7,8]} \mathrm{HCC}$ is associated with hypoglycemia, erythrocytosis, hypercalcemia, hypercholesterolemia and diarrhea. ${ }^{[9]}$

\section{ETIOLOGY OF HCC}

The distributions of HCC are largely result from various

This is an open access article distributed under the terms of the Creative Commons Attribution-NonCommercial-ShareAlike 3.0 License, which allows others to remix, tweak, and build upon the worknon-commercially, as long as the author is credited and the new creations are licensed under the identical terms.

For reprints contact: service@oaepublish.com

How to cite this article: Hassan HA, El-Gharib NE, Azhari AF. Role of natural antioxidants in the therapeutic management of hepatocellular carcinoma. Hepatoma Res 2016;2:216-23. 
risk factors particularly the majority of hepatitis $\mathrm{B}$ and $\mathrm{C}$ viral infection and alcoholic liver disease. ${ }^{[10]}$ Chronic HBV infection cause of HCC in different area, where the virus is largely endemic and vertical transmission common. ${ }^{[11,12]}$ High alcohol consumption; smoking of cigarette; obesity; and diabetes have also been associated with an increased risk of developing HCC. ${ }^{[13-15]}$ Previous studies have reported a close correlation with obesity and diabetes and an increased risk of HCC progression. ${ }^{[16]}$ Also, there are common environmental factor associated with HCC development such as aflatoxin, a product of the Aspergillus fungus. ${ }^{[17]}$ Several physiological disorders of the liver have been implicated in the HCC development, including $\alpha-1$ antitrypsin deficiency; certain porphyrias; Olchi's disease; and hereditary hemachromatosis, each typically in the setting of cirrhosis. ${ }^{[18]}$ Additionally, an automimmune disorders have been implicated in HCC pathogenesis, including primary biliary cirrhosis and autoimmune hepatitis. ${ }^{[19]}$

\section{PATHOPHYSIOLOGY OF HCC}

HCC majority occurs in the setting of liver cirrhosis. The accumulations of genetic and epigenetic changes related to hepatocarcinogenesis disease are well known. However, the regulating cell cycle and suppressing apoptosis used for maintenance the survival of cancerous cells. Retinoblastoma and p53 genes responsible for the oncogenes activation and tumor suppressor genes are the good markers that understand the molecular, physiological mechanisms and disorders in the cellular signaling pathways of HCC incidence growing. ${ }^{[20]}$ When the liver gets injured, necrosis will appear in the liver accompanied by the subsequent hepatocyte proliferation, after continuous cycles of destructive-regenerative process. The hyperplastic nodules will turn into dysplastic nodules inducing a high risk of developing HCC. ${ }^{[21]}$

Furthermore HCC well associated with various metabolic changes including biochemical alterations. Alfa-fetoprotein (AFP) is a glycoprotein in serum that was first recognized as a major marker for HCC. AFP elevation indicating to malignant after pathological diagnosis and endodermal lining tumor of the stomach, pancreas, and biliary tree. ${ }^{[22]}$ Moreover, HCC development has also been associated with plasma lipid and lipoprotein alterations. ${ }^{[23]}$ This alterations result in cellular dysfunction, reduction in the membrane integrity, fluidity and regulation of cellular processes related to growth and cell survival causing cancer development. ${ }^{[24,25]}$ The cirrhosis and HCC characterized by a decrease of total protein and impair hepatic function indicating by increasing hepatic enzymes (aspartate aminotransferase, alanine transaminase, alkaline phosphatase, and gamma glutamyl transferase) activity through the loss of functional integrity of the cell membrane in liver resulting liver damage. ${ }^{26-28]}$ Furthermore, the development and progression of HCC are well associated with the oxidative stress status that produced by increasing level of reactive oxygen species (ROS) resulting distortion and decrease the antioxidant activity in the tissues. ${ }^{[29,30]}$ Lipid peroxidation (LPO) is responsible for formation of many toxic products, such as 4-hydroxynonenal and malondialdehyde MDA which attack cellular targets, thereby inducing carcinogenicity ${ }^{[31-33]}$ Many biochemical and molecular changes leads to free radical metabolites causing the chemical carcinogens induce oxidative stress leading to tumor promotion. ${ }^{[34,35]}$ The failure of antioxidant defense mechanism and tissue damage were enhanced by increasing LPO. Glutathione (GSH) is present in high concentration of liver and widely distributed in cells. ${ }^{[36]}$ It has many properties as, protects the cell against free radical, peroxides and other toxins, so after decreased of GSH level in tissue causing DNA damage, protein oxidation and LPO of the cell membrane biomolecules lead to hepatocyte damage. ${ }^{[3]}$ However, the decrease of the antioxidant enzymes activity (superoxide dismutase and catalase) caused the increase of hepatocytes in the cirrhotic livers. The production of cytokines, ROS, and inflammation-mediated events leads to tumor formation. ${ }^{|38|}$ The inflammatory diseases of cell, is produced by many pro-inflammatory cytokine as TNF- $\alpha$ and structural cells especially the pathogenesis of asthma. ${ }^{[39}$ Liver cirrhosis causes elevated in the pro-inflammatory cytokine TNF- $\alpha$ as a major marker for inflammatory state in the cirrhotic liver ${ }^{[40]}$ HCC has an anti-apoptotic genes expression and rapid cell proliferation, ${ }^{[4]}$ due to apoptosis resistance under conventional therapies and incomplete cell cycle arrest. ${ }^{[42]}$ HCC increased apoptosis by the down-regulation of the Bcl2 level, the activation of caspase cascade, and the up-regulation of Bax and the $p 53$ level. ${ }^{[43-45]}$ Additionally, HCC contains various histological changes such as: (1) pseudoglandular pattern including gland-like dilatation of the canaliculi in tumor cells; and (2) trabecular pattern of growth. ${ }^{[46]}$ Cytologically; polygonal and displaying of tumoral hepatocytes; smaller tumor cell; granular eosinophilic cytoplasm; vesicular nuclei; giant tumor cells; and conspicuous nucleoli are associated with HCC. ${ }^{[46-48]}$

\section{MANAGEMENT AND PROGNOSIS OF HCC}

There is a wide heterogeneity in HCC pattern, patient variations as candidates for recommended treatments, and increasingly complex available therapeutic options with diverse responses to these therapies in clinical practice. ${ }^{[49]}$ Also HCC is highly associated with variable biologic behavior and the frequent coexistence of chronic liver disease and cirrhosis. ${ }^{[5]}$ So, it is important to manage HCC patients by multidisciplinary HCC teams including hepatologists; medical and surgical oncologists; transplantation surgeons; diagnostic and interventional radiologists; pathologists; nurses and nurse practitioners. ${ }^{[51]}$ The most commonly used treatment by the enhancement of latent antitumor immune response through chemotherapy. ${ }^{[52]}$ Chemotherapy has varying effects, and work is underway in the search for active chemotherapy and appropriate for chemo-embolization, an intensive localized chemotherapy method by using improvement prognosis. ${ }^{[53]}$ However, chemotherapy still has severe side effects and low survival rates. ${ }^{[54 \mid}$ As a recent reports, a large number of natural antioxidant extracts 
have been suggested to induce beneficial effects on human health and disease control. ${ }^{[55]}$ The beneficial effects of many medicinal plants may be due to the presence of antioxidative, antibacterial and antimicrobial components. Antioxidants such as flavonoids, phenolic acids and diterpenes can be used to treat the undesirable and harmful action of the free radicals related to various diseases. ${ }^{\text {[30] }}$

\section{THERAPEUTIC MANAGEMENT OF HCC BY NATURAL ANTIOXIDANTS}

Natural agents are alternative therapeutic agents to control different diseases including cancer progression through their antioxidant activity. They stimulate the normal metabolic function in cancer cells and regulate the tumor suppressor genes and immunity. These natural products control the over expression of metabolic enzymes and tumor growth factors in cancer cell. ${ }^{[56]}$ Also they have the ability to control DNA damaging factors in cancer cells and regulate DNA transcription in tumors. Moreover, they possess numerous therapeutic benefits such as anti-obesity effects; anti-diabetic effects; immune enhancement; and anti-inflammatory effects..$^{[57]}$ Previous studies recorded that natural extracts, herbs and spices have been used for controlling diseases, including cancer through different mechanisms such as prevention of tumor initiation; delay or arrest of the development of tumors; extension of cancer latency periods; reduction in cancer metastasis and mortality and prevention of recurrence of secondary tumors. ${ }^{[58,59]}$ Vegetables and fruits rich with polyphenol plays a crucial role in the protection of liver against hepatitis due to its potential activity in the reduction of early pro-inflammatory cytokines, activation of antiinflammatory IL-10, and inhibition of lipo-polysaccharide induced activation of nuclear factor kappa B (NF- $\mathrm{KB}$ ) in hepatocytes. ${ }^{[60-62]}$ Furthermore, flavonoids are a group of polyphenolic compounds, different in chemical structure and characteristics, naturally founded in plants. They showed versatile health benefits such as anti-inflammatory; antioxidant; anti-proliferative and anticancer activity; free radical scavenging activity; and antihypertensive effects. ${ }^{[3,644]}$

\section{Chicory}

Chicory (Cichorium intybus L.) has been reported in medicine from North Africa to South Asia for several 100 years. ${ }^{[65]}$ It contains many useful compound such as anthocyanins, vitamins $A$ and $C$, potassium, calcium, and phosphorus and rich chioric acid. ${ }^{[66]}$ It act as anti-inflamatory, anti-bacterial agent as well as it has immune-modulatory effects. ${ }^{[67]}$ Many types of edible plants and vegetables contain high level of chicoric acid. ${ }^{|68|}$ Chicoric acid have essential properties as antioxidant, antivirus and immunoregulation. ${ }^{[69]}$ Chicory has a many properties as antioxidant, hepatoprotective, hypoglycemic, diuretic, and anti-testicular toxicity. ${ }^{[0-73]}$ Also, chicory is a good source for inulin..$^{[74,75]}$ Inulin is a hepatoprotective compound that prevent of the tissue from demolition by inhibited oxidative degradation of DNA in liver mice. ${ }^{[74]}$ In addition, inulin has hypolipidemic effect where it is not affected by digestive enzymes due to it is expected to behave like a soluble fiber ${ }^{[76]}$ Moreover it has prebiotic effect by decreasing the activity of growth pathogens and harmful microorganisms as well as increase the activity of growth colonic of beneficial bacteria to the host. ${ }^{\mid 77,78]}$

\section{Milk thistle}

Milk (Silybum marianum) is one of the most famous herbal agents that act as hepato-reno protective agent from 16th century due to it contains approximately 4-6\% silymarin and 20-35\% fatty acids, particularly linoleic acid. ${ }^{[79,80]}$ Silymarin composed of both polyphenolic molecules, including flavonolignans (silybin A, silybin B, isosilybin A, isosilybin B, silychristin, isosilychristin, and silydianin) and one flavonoid (taxifolin), silibinin, a semipurified. These components have the beneficial effects, including liver protection and antioxidant, anti-viral, and anti-inflammatory properties. ${ }^{[81]}$ Silybum is effective in the treatment of liver diseases (cirrhosis, jaundice and hepatitis). ${ }^{[82]}$ Various studies including in vitro and animal research suggest that silybum may have hepatoprotective and antihepatotoxic properties that protect liver cells against toxins through its ability in the reduction of ROS and LPO production, as well as the rebalancing of cellular REDOX status. ${ }^{[81,83]}$ Moreover its role in inhibition of pro-inflammatory signals, cellular proliferation and expression of survival proteins, resulting a significant protecting the liver. ${ }^{[81]}$

\section{Glycyrrhizin}

Glycyrrhizin is the active constituent obtained from aqueous extraction of root liquorice (Glycyrrhiza glabra). It has been used in traditional medicine to reduce bronchitis, jaundice as well as gastritis. Its major constituents are glycyrrhetic acid; flavonoids; hydroxycoumarins; and beta-sitosterol. ${ }^{[84]}$ Licorice and their products have been reported to be useful in the treatment of human hepatitis; animal inducible hepatocarcinogenesis; and attenuating titanium dioxide nanoparticles-induced hepatotoxicity. ${ }^{[85]}$ Glycyrrhizin has pharmacologic roles such as anti-inflammatory; antiviral; antioxidant; immunomodulatory; hepatoprotective and cardioprotective activities through the inhibition of betahydroxysteroid dehydrogenase enzyme. ${ }^{[86]}$ Also it blinded to high mobility group box 1 (HMGB1) directly to suppress HMGB1-induced injury, inhibit toll-like receptor-4 pathway, lower uclear factor- $\mathrm{\kappa B}(\mathrm{NF}-\mathrm{\kappa B})$ concentration and inhibit the production of inflammatory cytokines. ${ }^{[87,88]}$

\section{Ginseng}

Ginseng (Panax ginseng), a valued Chinese and Korean traditional medicinal herb, has been clinically used in China, Europe, United States and North America for thousands of years. ${ }^{[89-91]}$ Ginseng is one of the well-known medicines in alleviating the development of HCC in chronic hepatitis patients. ${ }^{[92,93]}$ Ginseng extract has an antioxidant activity due to its ability to scavenge free radicals and suppression of lipid peroxidation. ${ }^{[94]}$ It has been shown to improve general conditions and non-specific complaints due to the exhaustive and feverish illness through enhancement of 
natural healing power. Also, it has been shown to prevent cancer development and inhibit carcinogenesis in several organs. ${ }^{[95,96]}$ Recent studies suggested the efficacy of ginseng extract to induce apoptosis so it has antitumor activity. ${ }^{[97-99]}$

\section{Dandelion}

Dandelion (Taraxacum officinale) has been used in traditional medicine in the treatment of inflammation and several diseases including cancer. ${ }^{[100]}$ It has anti-rheumatic and anti-inflamatory. ${ }^{[101-104]}$ Moreover it has antioxidant properties as well as hepatoprotective activity and success in promotion of liver detoxification and support kidney function. All of these beneficial effects may be attributed to their several flavonoids including caffeic acid; chlorogenic acid; luteolin; and luteolin-7-glucoside..$^{[105]}$ Additionally it is a rich source of vitamins A, B complex, $\mathrm{C}$, and $\mathrm{D}$, as well as minerals such as iron, potassium, and zinc. ${ }^{[106-109]}$ Dandelion extract showed a protective effect against membrane fragility consequently, and minimizing the leakage of liver enzymes into the blood circulation and suppressed the production of tumor necrosis factor (TNF)- $\alpha$ by inhibiting interleukin-1 production. ${ }^{[107,110]}$ Also it has been shown to have stronger free radicals scavenging activity due to its high polyphenol content. ${ }^{[101]}$

\section{Garlic}

Garlic (Allium sativum) has been widely used as a food stuff and a traditional medicine throughout the world. Garlic is available in different forms such as powder or garlic oil. Garlic has a beneficial value such as antiatherosclerotic, antihypertensive, antimicrobial, anticancer, immunomodulatory, antioxidant, and radioprotector

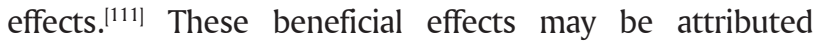
to its components including organo-sulfur compounds such as diallyl sulfide; diallyl disulfide; diallyl trisulfide; S-allylcysteine (SAC) and S-allylmercaptocysteine. ${ }^{[12]}$ Several studies evidences have proved that SAC is an anti-tumor agent against different human cancers such as prostate, ${ }^{[113]}$ breast, ${ }^{\mid 114]}$ oral ${ }^{\mid 115]}$ neuroblastoma ${ }^{[116]}$ and non-small-cell lung carcinoma ${ }^{\left[{ }^{[17]}\right.}$ On the otherhand, allicin(diallyl thiosulfonate), which is the main biologically active component of freshly crushed garlic cloves, has anti-hepatocarcinogenic effect through the p53 gene modulating apoptosis. ${ }^{[18]}$ Garlic oils have capable for promotion apoptotic signaling as evidenced by the upregulation of Bax and Caspase-3..$^{[119]}$ Also, garlic oil exhibited potent antioxidant capacity were it reduced the generation of ROS, suggesting that the different mechanisms of hepatocarcinoma prevention. ${ }^{[120]}$ Additionally, the major role of garlic extract rich in SAC against hepatocarcinogenesis as well as organs tumors may be due to its effect on inhibition of proliferation, induction of apoptosis and suppression of invasion and adhesion..$^{[115,121]}$

\section{Curcumin}

Curcumin (Curcuma longa) is turmeric spice derived from the rhizome of the East Indian plant Curcuma longa. ${ }^{[122]}$ It is a polyphenol contains a class of compounds such as curcuminoids, demethoxycurcumin and bisdemethoxycurcumin..$^{123]}$ Turmeric has also been widely used in medicine for cardioprotective, hepatoprotective, carcinoprotective, and neuroprotective in addition it acts as anti-oxidant, antiseptic, analgesic, antimalarial and anti-inflammatory. ${ }^{[124]}$ Curcumin rich in curcuminoids are known to inhibit oxidation owing to their methoxy group, 1, 3 B-diketone moiety and phenolic hydroxyl group so it can decrease the free radicals generation, which it was an important step in tumor formation. ${ }^{\mid 125]}$ Curcumin was found to inhibit NF- $\mathrm{kB}$, which activates inflammatory cytokines and chemokines, leading to several inflammatory conditions..$^{[126]}$ NF- $\mathrm{KB}$ activation promotes cellular proliferation, angiogenesis, and invasion and inhibits apoptosis. ${ }^{\mid 127]}$ In addition, curcumin also inhibits IL1, IL1B, IL6, IL8, tumor necrosis alpha, and cyclooxygenase pathways. ${ }^{|128|}$ Several studies have supported curcumin's antioxidant and antiinflammatory, particularly in HCC in addition to its ability to control the cellular signal transduction pathways pertinent to growth, differentiation, and malignant transformation. ${ }^{[129,130]}$

\section{Thyme}

Thyme (Thymus vulgaris) is widely used in folk medicine for the treatment of a variety of diseases including gastroenteric and bronchopulmonary disorders specially in almost everywhere in the world. It is effective as anthelmintic, antispasmodic, carminative, sedative, diaphoretic, antimicrobial, antioxidant, and antifungal agents because its contents of essential oils and anti-oxidative phenolic compounds [geraniol $(\mathrm{G}), \alpha$-terpineol $(\mathrm{A})$, thuyanol-4 (U), linalool (L), carvacrol (C), and thymol $(\mathrm{T})]^{\left[{ }^{[131,132]}\right.}$ The volatile oils of thyme has been shown to exhibit anti-microbial, anti-mutagenic, anti-platelet, analgesic, anti-inflammatory, anti-angiogenic, anti-oxidant, anti-elastase, insecticidal, anti-parasitic, cell-protective, and anti-tumor activity. ${ }^{\mid 133,134]}$ Recently, the various studies showed that the beneficial effects of thyme was based on the activation of the apoptosis response, including reduction in mitochondrial membrane capacity and $\mathrm{Bcl}-2 / \mathrm{Bax}$ ratio as well as elevation in cytochrome release from mitochondria and caspase activity. Furthermore, it increases the cleavage of PARP and fragmentation of DNA, which belong to the mitochondrial pathway of the apoptosis pathway. ${ }^{\mid 135]}$

\section{CONCLUSION}

In conclusion, HCC is the common malignancy of the liver that considered one of death reasons in the worldwide. Chronic infection of HBV and HCV and subsequent liver injury regeneration cycle are considered a major etiology of HCC. HCC is well accepting for multi-drug resistance and not response to current chemotherapeutic agents. Nowadays, no single or combined chemotherapy regimen has been found yet to be effective in HCC. Traditional medicine, especially the herbal medicine plays a vital role in the management of various liver disorders. In this era of science and technology the demand for therapeutic drugs from natural products is increasing day by day, due to their effective therapeutic action and lack of side effects. Recent 
studies have shown that medicinal herbs and natural agents rich in antioxidants and other safety micronutrients protect against hepatic dysfunction, carcinogenesis, mutagenesis, DNA-damage and LPO. The greatly positive effect of natural antioxidants on membrane stabilizing by mechanisms that include up-regulation of the key apoptotic regulators, modulate cell cycle arrest and improvement of DNA content by the free radical scavenging, the antimutagenic and antioxidant properties. Thus, it was recommended that the supplementation with edible natural agents may help in safe application of cancer technology in medicine as well as in many other aspects of nowadays life.

\section{Financial support and sponsorship}

Nil.

\section{Conflicts of interest}

There are no conflicts of interest.

\section{REFERENCES}

1. Jemal A, Bray F, Center MM, Ferlay J, Ward E, Forman D. Global cancer statistics. CA Cancer J Clin 2011;61:69-90.

2. Marquardt JU, Galle PR, Teufel A. Hepatocellular carcinoma molecular pathogenesis and novel targets for therapy. Dutch Med Wochenschr 2012;137:855-60

3. Poon D, Anderson BO, Chen LT, Tanaka K, Lau WY, Van Cutsem E, Singh H, Chow WC, Ooi LL, Chow P, Khin MW, Koo WH; Asian Oncology Summit. Management of hepatocellular carcinoma in Asia: consensus statement from the Asian Oncology Summit 2009. Lancet Oncol 2009; 10:1111-8.

4. Gomaa AI, Khan SA, Toledano MB, Waked I, Taylor-Robinson SD. Hepatocellular carcinoma: epidemiology, risk factors and pathogenesis. World J Gastroenterol 2008;14:4300-8.

5. Velázquez RF, Rodríguez M, Navascués CA, Linares A, Pérez R, Sotorríos NG, Martínez I, Rodrigo L. Prospective analysis of risk factors for hepatocellular carcinoma in patients with liver cirrhosis. Hepatol J 2003;37:520-7.

6. Choi BG, Park SH, Byun JY, Jung SE, Choi KH, Han JY. The findings of ruptured hepatocellular carcinoma on helical CT. $\mathrm{Br} J$ Radiol 2001;74:142-6.

7. Kew MC. Tumors of the liver. In: Zakim D, Boyer T, editors. Hepatology: A textbook of liver disease. 3rd ed. Philadelphia: WB Saunders Company; 1996. p.1513.

8. Rossetto D, Truman AW, Kron SJ, Côté J. Epigenetic modifications in double-strand break DNA damage signaling and repair. Clin Cancer Res 2010;16:4543-52.

9. Kassianides C, Kew MC. The clinical manifestations and natural history of hepatocellular carcinoma. Gastroenterol Clin North Am 1987; 16:553-62.

10. McGlynn KA, London WT. The global epidemiology of hepatocellular carcinoma: present and future. Clin Liver Dis 2011;15:223-43.

11. El-Serag HB. Hepatocellular carcinoma. NEngl JMed 2011;365:1118-27.

12. Bruix J, Sherman M; Practice Guidelines Committee, American Association for the Study of Liver Diseases. Management of hepatocellular carcinoma. Hepatology 2005;42:1208-36.

13. Besaratinia A, Kim SI, Hainaut P, Pfeifer GP. In vitro recapitulating of TP53 mutagenesis in hepatocellular carcinoma associated with dietary aflatoxin B1 exposure. Gastroenterology 2009;137:1127-37.

14. Donato F, Tagger A, Gelatti U, Parrinello G, Boffetta P, Albertini A, Decarli A, Trevisi P, Ribero ML, Martelli C, Porru S, Nardi G. Alcohol and hepatocellular carcinoma: the effect of lifetime intake and hepatitis virus infections in men and women. Am J Epidemiol 2002;155: 323-31.

15. Trichopoulos D, Bamia C, Lagiou P, Fedirko V, Trepo E, Jenab M, Pischon T, Nöthlings U, Overved K, Tjønneland A, Outzen M, Clavel-
Chapelon F, Kaaks R, Lukanova A, Boeing H, Aleksandrova K, Benetou V, Zylis D, Palli D, Pala V, Panico S, Tumino R, Sacerdote C, Bueno-De-Mesquita HB, Van Kranen HJ, Peeters PH, Lund E, Quirós JR, González CA, Sanchez Perez MJ, Navarro C, Dorronsoro M, Barricarte A, Lindkvist B, Regnér S, Werner M, Hallmans G, Khaw KT, Wareham N, Key T, Romieu I, Chuang SC, Murphy N, Boffetta P, Trichopoulou A, Riboli E. Hepatocellular carcinoma risk factors and disease burden in a European cohort: a nested case-control study. J Natl Cancer Inst 2011;103:1686-95.

16. Regimbeau JM, Abdalla EK, Vauthey JN, Lauwers GY, Durand F, Nagorney DM, Ikai I, Yamaoka Y, Belghiti J. Risk factors for early death due to recurrence after liver resection for hepatocellular carcinoma: results of a multicenter study. J Surg Oncol 2004;85:36-41.

17. Sanyal AJ, Yoon SK, Lencioni R. The etiology of hepatocellular carcinoma and consequences for treatment. Oncologist 2010;4:14-22.

18. Dragani TA. Risk of HCC: genetic heterogeneity and complex genetics. J Hepatol 2010;52:252-7.

19. Sohal DP, Sun W. Hepatocellular carcinoma: prevention and therapy. Curr Oncol Rep 2011;13:186-94.

20. Aravalli RN, Steer CJ, Cressman EN. Molecular mechanisms of hepatocellular carcinoma. Hepatology 2008;48:2047-63.

21. Farazi PA, Glickman J, Horner J, Depinho RA. Cooperative interactions of p53 mutation, telomere dysfunction, and chronic liver damage in hepatocellular carcinoma progression. Cancer Res 2006;66:4766-73.

22. Bialecki ES, Di Bisceglie AM. Diagnosis of hepatocellular carcinoma. HPB (Oxford) 2005;7: 26-34.

23. Jiang J, Nilsson-Ehle $\mathrm{P}, \mathrm{Xu} \mathrm{N}$. Influence of liver cancer on lipid and lipoprotein metabolism. Lipids Health Dis 2006;5:4.

24. Das UN, Madhavi N, Sravan Kumar G, Padma M, Sangeetha P. Can tumor cell drug resistance be reversed by essential fatty acids and their metabolites? Prostaglandins Leukot Essent Fatty Acids 1998;58:39-54

25. Tapiero H, Ba GN, Couvreur P, Tew KD. Polyunsaturated fatty acids (PUFA) and eicosanoids in human health and pathologies. Biomed Pharmacother 2002;56:215-22.

26. Honarmand H, Mirzajani E, Rahbar-Taromsari M, Saadat F, Mirblock F, Mashayekhi F. The relationship and diagnostic value of C-reactive protein (CRP) and C-reactive protein (hsCRP) for myocardial infarction. Afr J Microbiol Res 2011;5:3215-9.

27. Hutchinson DR, Halliwell RP, Smith MG, Parke DV. Serum "prealbumin" as an index of liver function in human hepatobiliary disease. Clin Chem Acta 1981;114:69-74.

28. Ahmed KM, Saleh EM, Sayed EM, Shalaby KAF. Anti-inflammatory effect ofdifferent propolis extracts in thioacetamide-induced hepatotoxicity in male rat. Aust J Basic App Sci 2012;6:29.

29. Marra M, Sordelli IM, Lombardi A, Lamberti M, Tarantino L, Giudice A, Stiuso P, Abbruzzese A, Sperlongano R, Accardo M, Agresti M, Caraglia M, Sperlongano P. Molecular targets and oxidative stress biomarkers in hepatocellular carcinoma: an overview. J Transl Med 2011;9:171.

30. Hassan HA, Edrees GM, El-Gamel EM, El-Sayed EA. Amelioration of cisplatin-induced nephrotoxicity by grape seed proanthocynidin extract and fish oil is mediated by lowering oxidative stress and DNA damage. Cytotechnology 2014;66:419-29.

31. Banakar MC, Paramasivan SK, Chattopadhyay MB, Datta S, Chakraborty P. 1alpha, 25-dihydroxyvitamin D3 prevents DNA damage and restores antioxidant enzymes in rat hepatocarcinogenesis induced by diethylnitrosamine and promoted by phenobarbital. World $J$ Gastroenterol 2004;10:1268-75.

32. Revathi R, Manju V. The effects of Umbelliferone on lipid peroxidation and antioxidant status in diethylnitrosamine induced hepatocellular carcinoma. Acute J Med 2013;3:73-82.

33. Chen B, Ning M, Yang G. Effect of paeonol on antioxidant and immune regulatory activity in hepatocellular carcinoma rats. Molecules 2012;17:4672-83.

34. Trush MA, Kensler TW. Role of free radicals in carcinogenic activation In: Sies H, editor. Oxidative Stress: Oxidants and Antioxidants. London, UK: Academic Press; 1991. p. 277-318.

35. Ljubuncic P, Song H, Cogan U, Azaizeh H, Bomzon A. The effects of aqueous extracts prepared from the leaves of Pastacia lentiscus in 
experimental liver disease. J Ethnopharmacol 2005;100:198-204

36. Ahmad A, Pillai KK, Najmi AK, Ahmad SJ, Pal SN, Balani DK. Evaluation of hepatoprotective potential of jigrine post-treatment against thioacetamide induced hepatic damage. J Ethnopharmacol 2002;79:35-41.

37. Chilakapati J, Korrapati MC, Hill RA, Warbritton A, Latendresse JR, Mehendale HM. Toxicokinetics and toxicity of thioacetamide sulfoxide: a metabolite of thioacetamide. Toxicology 2007;230:105-16.

38. Cervello M, Montalto G. Cyclooxygenases in hepatocellular carcinoma. World J Gastroenterol 2006;12:5113-21.

39. Coward WR, Okayama Y, Sagara H, Wilson SJ, Holgate ST, Church MK. NF-kappa B and TNF-alpha: a positive autocrine loop in human lung mast cells? J Immunol 2002; 169:5287-93.

40. Zaret KS, Grompe M. Generation and regeneration of cells of the liver and pancreas. Science 2008;322:1490-4.

41. Lee S, Lee HJ, Kim JH, Lee HS, Jang JJ, Kang GH. Aberrant CpG island hypermethylation along multistep hepatocarcinogenesis. Am J Pathol 2003;163:1371-8.

42. Nishikawa H, Kato T, Tawara I, Ikeda H, Kuribayashi K, Allen PM, Schreiber RD, Old LJ, Shiku H. IFN-gamma controls the generation/ activation of $\mathrm{CD} 4+\mathrm{CD} 25+$ regulatory $\mathrm{T}$ cells in antitumor immune response. J Immunol 2005;175:4433-40.

43. Huether A, Hopfner M, Sutter AP, Baradari V, Schuppan D, Scherubl H. Signaling pathways involved in the inhibition of epidermal growth factor receptor by erlotinib in hepatocellular cancer. World $J$ Gastroenterol 2006;12:5160-7.

44. Hu S, Chen SM, Li XK, Qin R, Mei ZN. Antitumor effects of chishen extract from Salvia miltiorrhiza and Paeoniae radix on human hepatocellular carcinoma cells. Acta Pharmacol Sin 2007;28:1215-23.

45. Youle RJ, Strasser A. The BCL-2 protein family: opposing activities that mediate cell death. Nat Rev Mol Cell Biol 2008;9:47-59.

46. Paradis V. Histopathology of hepatocellular carcinoma. In: Vauthey $\mathrm{JN}$, Brouquet A, editors. Multidisciplinary treatment of hepatocellular carcinoma. Berlin: Springer; 2013. p. 21-32.

47. Omata M, Peters RL, Tatter D. Sclerosing hepatic carcinoma: relationship to hypercalcemia. Liver 1981;1:33-49.

48. Kojiro M, Sugihara S, Kakizoe S, Nakashima O, Kiyomatsu K. Hepatocellular carcinoma with sarcomatous change: a special reference to the relationship with anticancer therapy. Can Chemother Pharmacol 1989;23:S4-8.

49. Guy J, Kelley RK, Roberts J, Kerlan R, Yao F, Terrault N. Multidisciplinary management of hepatocellular carcinoma. Clin Gastroenterol Hepatol 2012;10:354-62.

50. Kaseb AO, Abaza YM, Roses RE. Multidisciplinary management of hepatocellular carcinoma. Recent Results Cancer Res 2013;190:247-59.

51. Gish RG, Lencioni R, Di Bisceglie AM, Raoul JL, Mazzaferro V. Role of the multidisciplinary team in the diagnosis and treatment of hepatocellular carcinoma. Expert Rev Gastroenterol Hepatol 2012;6:173-85.

52. Osaki A, Suda T, Kamimura K, Tsuchiya A, Tamura Y, Takamura M, Igarashi M, Kawai H, Yamagiwa S, Aoyagi Y. A safe and effective dose of cisplatin in hepatic arterial infusion chemotherapy for hepatocellular carcinoma. Cancer Med 2013;2:86-98.

53. Mok TS, Leung TW, Lee SD, Chao Y, Chan AT, Huang A, Lui MC, Yeo W, Chak K, Johnston A, Johnson P. A multi-centre randomized phase II study of nolatrexed versus doxorubicin in treatment of Chinese patients with advanced hepatocellular carcinoma. Cancer Chemother Pharmacol 1999;44:307-11.

54. Leichman CG, Jacobson JR, Modiano M, Daniels JR, Zalupski MM, Doroshow JH, Fletcher WS, Macdonald JS. Hepatic chemoembolization combined with systemic infusion of 5-fluorouracil and bolus leucovorin for patients with metastatic colorectal carcinoma: a Southwest Oncology Group pilot trial. Cancer 1999;86:775-81.

55. Hassan HA, El-Gharib NE. Obesity and clinical riskiness relationship: therapeutic management by dietary antioxidant supplementation-a review. Appl Biochem Biotechnol 2015;176:647-69.

56. Kuppusamy P, Yusoff MM, Maniam GP, Ichwan SJ, Soundharrajan I, Govindan N. Nutraceuticals as potential therapeutic agents for colon cancer: a review. Acta Pharm Sinica B 2014;4:173-81.
57. Sousa GT, Lira FS, Rosa JC, de Oliveira EP, Oyama LM, Santos RV, Pimentel GD. Dietary whey protein lessens several risk factors for metabolic diseases: a review. Lipids Health Dis 2012;11:67.

58. Kapadia GJ, Azuine MA, Takayasu J, Konoshima T, Takasaki M, Nishino H, Tokuda H. Inhibition of epstein-barr virus early antigen activation promoted by 12-O-tetradecanoylphorbol-13-acetate by the non-steroidal anti-inflammatory drugs. Cancer Lett 2000;161:221-9.

59. Kelloff GJ. Perspectives on cancer chemoprevention research and drug development. Adv Cancer Res 2000;78:199-334.

60. Bravo L. Polyphenols: chemistry, dietary sources, metabolism, and nutritional significance. Nutr Rev 1998;56:317-33.

61. Yamashita H, Goto M, Matsui-Yuasa I, Kojima-Yuasa A. Ecklonia cava polyphenol has a protective effect against ethanol-induced liver injury in a cyclic AMP-dependent manner. Mar Drugs 2015;13:3877-91.

62. Manach C, Scalbert A, Morand C, Rémésy C, Jiménez L. Polyphenols: food sources and bioavailability. Am J Clin Nutr 2004;79:727-47.

63. Xiao ZP, Peng ZY, Peng MJ, Yan WB, Ouyang YZ, Zhu HL. Flavonoids health benefits and their molecular mechanism. Mini Rev Med Chem 2011;11:169-77.

64. Donfack JH, Simo CC, Ngameni B, Tchana AN, Kerr PG, Finzi PV, Vidari G, Giardina S, Buonocore D, Ngadjui BT, Moundipa PF, Marzatico F. Antihepatotoxic and antioxidant activities of methanol extract and isolated compounds from Ficus chlamydocarpa. Nat Prod Commun 2010;5:1607-12.

65. Jamshidzadeha A, Khoshnooda JM, Dehghanib Z, Niknaha H. Hepatoprotective activity of Cichorium intybus L. leaves extract against carbon tetrachloride induced toxicity. Iran J Pharm Res 2006;1:41-6.

66. Mulabagal V, Wang H, Ngouajio M, Nair MG. Characterization and quantification of health beneficial anthocyanins in leaf chicory (Cichorium intybus) varieties. Eur Food Res Technol 2009;230:47-53.

67. Nayeemunnisa A. Alloxan diabetes-induced oxidative stress and impairment of oxidative defense system in rat brain: neuroprotective effects of cichorium intybus. Int J Diabetes Metabol 2009;17:105-9.

68. Lee J, Scagel CF. Chicoric acid found in basil (Ocimum basilicum L.) leaves. Food Chem 2009;115:650-6.

69. Dalby-Brown L, Barsett H, Landbo AK, Meyer AS, Mølgaard P. Synergistic antioxidative effects of alkamides, caffeic acid derivatives, and polysaccharide fractions from Echinacea purpurea on in vitro oxidation of human low-density lipoproteins. Agric J Food Chem 2005;53:9413-23.

70. Hassan HA. The prophylactic role of some edible wild plants against nitrosamine precursor's experimentally-induced testicular toxicity in male albino rats. J Egypt Soc Toxicol 2008;38:1-11.

71. Pool-Zobel B, van Loo J, Rowland I, Roberfroid MB. Experimental evidences on the potential of prebiotic fructans to reduce the risk of colon cancer. Br J Nutr 2002;87:273-81.

72. Cavin C, Delannoy M, Malnoe A, Debefve E, Touché A, Courtois D, Schilter B. Inhibition of the expression and activity of cyclooxygenase-2 by chicory extract. Biochem Biophys Res Commun 2005;327:742-9.

73. Kim JH, Mun YJ, Woo WH, Jeon KS, An NH, Park JS. Effects of the ethanol extract of Cichorium intybus on the immunotoxicity by ethanol in mice. Int Immunopharmacol 2002;2:733-44.

74. Kolida S, Tuohy K, Gibson GR. Prebiotic effect of inulin and oligofructose. Br J Nutr 2002;87:S193-7.

75. Van Beek TA, Maas P, King BM, Leclercq E, Voragen AGJ, De Groot A. Bitter sesquiterpene lactones from chicory roots. Agric J Food Chem 1990;38:1035-8.

76. Kim M, Shin HK. The water-soluble extract of chicory influences serum and liver lipid concentrations, cecal short-chain fatty acid concentrations and fecal lipid excretion in rats. JNutr 1998;128:1731-6.

77. Roberfroid MB. Inulin-type fructans: functional food ingredients. $J$ Nutr 2007;137:S2493-502.

78. Buriti FCA, Cardarelli HR, Filisetti TMCC, Saad SMI. Synbiotic potential of fresh cream cheese supplemented with inulin and Lactobacillus paracasei in co-culture with Streptococcus thermophilus. Food Chem 2007;104:1605-10.

79. Greenlee H, Abascal K, Yarnell E, Ladas E. Clinical applications of silybum marianum in oncology. Integr Cancer Ther 2007;6:158-65.

80. Kroll DJ, Shaw HS, Oberlies NH. Milk thistle nomenclature: why it 
matters in cancer research and pharmacokinetic studies. Integr Cancer Ther 2007:6:110-9.

81. Abenavoli L, Capasso R, Milic N, Capasso F. Milk thistle in liver diseases: past, present, future. Phytother Res 2010;24:1423-32.

82. Wang L, Waltenberger B, Pferschy-Wenzig EM, Blunder M, Liu X, Malainer C, Blazevic T, Schwaiger S, Rollinger JM, Heiss EH, Schuster D, Kopp B, Bauer R, Stuppner H, Dirsch VM, Atanasov AG. Natural product agonists of peroxisome proliferator-activated receptor gamma (PPAR $\gamma$ ): a review. Biochem Pharmacol 2014;92:73-89.

83. Al-Anati L, Essid E, Reinehr R, Petzinger E. Silibinin protects OTAmediated TNF-alpha release from perfused rat livers and isolated rat Kupffer cells. Mol Nutr Food Res 2009;53:460-6.

84. Fiore C, Eisenhut M, Ragazzi E, Zanchin G, Armanini D. A history of the therapeutic use of liquorice in Europe. $J$ Ethnopharmacol 2005;99:317-24.

85. Orazizadeh M, Fakhredini F, Mansouri E, Khorsandi L. Effect of glycyrrhizic acid on titanium dioxide nanoparticles-induced hepatotoxicity in rats. Chem Biol Interact 2014;220:214-21.

86. Asl MN, Hosseinzadeh $\mathrm{H}$. Review of pharmacological effects of Glycyrrhiza sp. and its bioactive compounds. Phytother Res 2008;22:709-24.

87. Gwak GY, Moon TG, Lee DH, Yoo BC. Glycyrrhizin attenuates HMGB1-induced hepatocyte apoptosis by inhibiting the p38-dependent mitochondrial pathway. World J Gastroenterol 2012;18:679-84.

88. Furuta K, Sato S, Miyake T, Okamoto E, Ishine J, Ishihara S, Amano Y, Adachi K, Kinoshita Y. Anti-tumor effects of cimetidine on hepatocellular carcinomas in diethylnitrosamine-treated rats. Oncol Rep 2008;19:361-8.

89. El Denshary ES, Al-Gahazali MA, Mannaa FA, Salem HA, Hassan NS, Abdel-Wahhab MA. Dietary honey and ginseng protect against carbon tetrachloride-induced hepatonephrotoxicity in rats. Exp Toxicol Pathol 2012;64:753-60.

90. Soldati F. Panax ginseng: standardization and biological activity. In: Cutler SJ, Cutler HG, editors. Biologically active natural products: pharmaceuticals. Boca Raton, FI: CRC Press, 2000. p. 209-32.

91. Barnes PM, Powell-Griner E, McFann K, Nahin RL. Complementary and alternative medicine use among adults: United States, 2002. Adv Data 2004;27:1-19.

92. Oka H, Yamamoto S, Kuroki T, Harihara S, Marumo T, Kim SR, Monna T, Kobayashi K, Tango T. Prospective study of chemoprevention of hepatocellular carcinoma with Sho-saiko-to (TJ-9). Cancer 1995;76:743-9.

93. Abdel-Wahhab MA, Gamil K, El-Kady AA, El-Nekeety AA, Naguib KM. Therapeutic effects of korean red ginseng extract in egyptian patients with chronic liver diseases. Ginseng J Res 2011;35:69-79.

94. He SX, Luo JY, Wang YP, Wang YL, Fu H, Xu JL, Zhao G, Liu EQ. Effects of extract from Ginkgo biloba on carbon tetrachloride-induced liver injury in rats. World J Gastroenterol 2006;12:3924-8.

95. Nishino H, Tokuda H, Ii T, Takemura M, Kuchide M, Kanazawa M, Mou XY, Bu P, Takayasu J, Onozuka M, Masuda M, Satomi Y, Konoshima T, Kishi N, Baba M, Okada Y, Okuyama T. Cancer chemoprevention by ginseng in mouse liver and other organs. $J$ Korean Med Sci 2001;16:S66-9.

96. Yun TK, Choi SY. Preventive effect of ginseng intake against various human cancers: a case-control study on 1987 pairs. Cancer Epidemiol Biomarkers Prev 1995;4:401-8.

97. Hasegawa H, Sung JH, Matsumiya S, Uchiyama M. Main ginseng saponin metabolites formed by intestinal bacteria. Planta Med 1996;62:453-7.

98. Lee BM, Lee SK, Kim HS. Inhibition of oxidative DNA damage, 8-OHdG, and carbonyl contents in smokers treated with antioxidants (vitamin E, vitamin C, beta-carotene and red ginseng). Cancer Lett 1998;132:219-27.

99. Choi HH, Jong HS, Park JH, Choi S, Lee JW, Kim TY, Otsuki T, Namba $\mathrm{M}$, Bang YJ. A novel ginseng saponin metabolite induces apoptosis and down-regulates fibroblast growth factor receptor 3 in myeloma cells. Int J Oncol 2003;23:1087-93.

100. Choi UK, Lee OH, Yim JH, Cho CW, Rhee YK, Lim SI, Kim YC. Hypolipidemic and antioxidant effects of dandelion (taraxacum officinale) root and leaf on cholesterol-fed rabbits. Int $J \mathrm{Mol} \mathrm{SCi}$ 2010;11:67-78.

101. Schütz K, Carle R, Schieber A. Taraxacum--a review on its phytochemical and pharmacological profile. $J$ Ethnopharmacol 2006;107:313-23.

102. Wichtl M. Herbal drugs and phytopharmaceuticals. A handbook for practice on a scientific basis. 3rd ed. Boca Raton, FI: CRC Press; 2004. p.704.

103. Newall CA, Anderson LA, Phillipson JD. Herbal medicines: a guide for health-care professionals. London: Pharmaceutical Press; 1996. p. 296.

104. Jeon HJ, Kang HJ, Jung HJ, Kang YS, Lim CJ, Kim YM, Park EH. Anti-inflammatory activity of Taraxacum officinale. J Ethnopharmacol 2008:115:82-8.

105. Williams CA, Goldstone F, Greenham J. Flavonoids, cinnamic acids and coumarins from the different tissues and medicinal preparations of Taraxacum officinale. Phytochemistry 1996;42:121-7.

106. Hu C, Kitts DD. Antioxidant, prooxidant, and cytotoxic activities of solvent-fractionated dandelion (Taraxacum officinale) flower extracts in vitro. J Agric Food Chem 2003;1:301-10

107. Al-Malki AL, Abo-Golayel MK, Abo-Elnaga G, Al-Beshri H. Hepatoprotective effect of dandelion (Taraxacum officinale) against induced chronic liver cirrhosis. Med Plants Res 2013;7:1494-505.

108. Park JY, Park CM, Kim JJ, Song YS. Hepatoprotective activity of dandelion (Taraxacum officinale) water extract against Dgalactosamineinduced hepatitis in rats. Korean J Soc Food Sci Nut 2008;32:177-83.

109. Hudec J, Burdová M, Kobida L, Komora L, Macho V, Kogan G, Turianica I, Kochanova R, Ložek O, Habán M, Chlebo P. Antioxidant capacity changes and phenolic profile of Echinacea purpea, nettle (Urtica dioica L.), and dandelion (Taraxacum officinale) after application of polyamine and phenolic biosynthesis regulators. Agric $J$ Food Chem 2007;55:5689-96.

110. Seo SW, Koo HN, An HJ, Kwon KB, Lim BC, Seo EA, Ryu DG, Moon G, Kim HY, Kim HM, Hong SH. Taraxacum officinale protects against cholecystokinin-induced acute pancreatitis in rats. World $J$ Gastroenterol 2005;11:597-9.

111. Rana SV, Pal R, Vaiphei K, Sharma SK, Ola RP. Garlic in health and disease. Nutr Res Rev 2011;24:60-71.

112. Herman-Antosiewicz A, Singh SV. Signal transduction pathways leading to cell cycle arrest and apoptosis induction in cancer cells by Allium vegetable-derived organosulfur compounds: a review. Mutat Res 2004;555:121-31.

113. Chu Q, Lee DT, Tsao SW, Wang X, Wong YC. S-allylcysteine, a water-soluble garlic derivative, suppresses the growth of a human androgen-independent prostate cancer xenograft, CWR22R, under in vivo conditions. BJU Int 2007;99:925-32.

114. Gapter LA, Yuin OZ, Ng KY. S-Allylcysteine reduces breast tumor cell adhesion and invasion. Biochem Biophys Res Commun 2008;367:446-51.

115. Tang FY, Chiang EP, Chung JG, Lee HZ, Hsu CY. S-allylcysteine modulates the expression of E-cadherin and inhibits the malignant progression of human oral cancer. J Nutr Biochem 2009;20:1013-20.

116. Welch C, Wuarin L, Sidell N. Antiproliferative effect of the garlic compound S-allyl cysteine on human neuroblastoma cells in vitro. Cancer Lett 1992;63:211-9.

117. Tang FY, Chiang EP, Pai MH. Consumption of S-allylcysteine inhibits the growth of human non-small-cell lung carcinoma in a mouse xenograft model. J Agric Food Chem 2010;58:11156-64.

118. Chu YL, Ho CT, Chung JG, Raghu R, Lo YC, Sheen LY. Allicin induces anti-human liver cancer cells through the $\mathrm{p} 53$ gene modulating apoptosis and autophagy. J Agric Food Chem 2013;61:9839-48.

119. Bryja V, Gradl D, Schambony A, Arenas E, Schulte G. Beta-arrestin is a necessary component of Wnt/beta-catenin signaling in vitro and in vivo. Proc Natl Acad Sci U S A 2007;104:6690-5.

120. Zhang CL, Zeng T, Zhao XL, Yu LH, Zhu ZP, Xie KQ. Protective effects of garlic oil on hepatocarcinoma induced by $\mathrm{N}$-nitrosodiethylamine in rats. Int J Biol Sci 2012;8:363-74.

121. Sundaresan S, Subramanian P. Prevention of N-nitrosodiethylamineinduced hepatocarcinogenesis by S-allylcysteine. Mol Cell Biochem 2008;310:209-14. 
122. Darvesh AS, Aggarwal BB, Bishayee A. Curcumin and liver cancer: a review. Curr Pharm Biotechnol 2012;13:218-28.

123. Jurenka JS. Anti-inflammatory properties of curcumin, a major constituent of curcima longa: a review of preclinical and clinical research. Altern Med Rev 2009;14:141-53.

124. Aggarwal BB, Sundaram C, Malani N, Ichikawa H. Curcumin: the Indian solid gold. Adv Exp Med Biol 2007;595:1-75.

125. Reyes-Gordillo K, Segovia J, Shibayama M, Vergara P, Moreno MG, Muriel P. Curcumin protects against acute liver damage in the rat by inhibiting NF-kappa B, proinflammatory cytokines production and oxidative stress. Biochim Biophys Acta 2007;1770:989-96.

126. Hsu FT, Liu YC, Liu TT, Hwang JJ. Curcumin sensitizes hepatocellular carcinoma cells to radiation via suppression of radiation-induced NF$\kappa \mathrm{B}$ activity. Biomed Res Int 2015;2015:363671.

127. Soliman MM, BaiomyAA, Yassin MH. Molecular and histopathological study on the ameliorative effects of curcumin against lead acetateinduced hepatotoxicity and nephrotoxicity in Wistar rats. Biol Trace Elem Res 2015;167:91-102.

128. Skommer J, Wlodkowic D, Pelkonen J. Gene-expression profiling during curcumin-induced apoptosis reveals downregulation of CXCR4. Exp Hematol 2007;35:84-95.
129. Dai XZ, Yin HT, Sun LF, Hu X, Zhou C, Zhou Y, Zhang W, Huang XE, Li XC. Potential therapeutic efficacy of curcumin in liver cancer. Asian Pac J Cancer Prev 2013;14:3855-9.

130. Aggarwal BB, Kumar A, Bharti AC. Anticancer potential of curcumin: preclinical and clinical studies. Anticancer Res 2003;23:363-98.

131. Hamzawy MA, El-Denshary ES, Hassan NS, Manaa F, Abdel-Wahhab MA. Antioxidant and hepatorenoprotective effects of Thyme vulgaris extract in rats during aflatoxicosis. Glob J Pharmacol 2012;6:106-17.

132. Hamzawy MA, El-Denshary ESM, Abdel-Wahhab MA. Effects of natural compounds in treatment and prevention of hepatotoxicity and hepatocellular carcinoma. Hepatoma Res 2015;1:111-8.

133. Hosseinzadeh S, Kukhdan AJ, Hosseini A, Armand R. The application of Thymus vulgaris in traditional and modern medicine: a review. Global J Pharmacol 2015;9:260-6.

134. Marculescu A, Vlase L, Hanganu D, Dragulescu C, Antonie I, NeliKinga O. Polyphenols analyses from Thymus species. Proc Rom Acad Series B 2007;3:117-21.

135. Thompson JD, Chalchat JC, Michet A, Linhart YB, Ehlers B. Qualitative and quantitative variation in monoterpene co-occurrence and composition in the essential oil of Thymus vulgaris chemotypes. $J$ Chem Ecol 2003;29:859-80. 